\title{
Assessing Physico-Chemical Parameters of Potable Water in Dhankuta Municipality of Nepal
}

\author{
Surya Dev Prasad Yadav ${ }^{1}$, Kalpana Mishra ${ }^{2}$, Narendra Kumar Chaudhary², Parashuram Mishra ${ }^{2}$, \\ ${ }^{1}$ Department of Chemistry, Dhankuta Multiple Campus, Dhankuta, Nepal \\ ${ }^{2}$ Bio-inorganic and Materials Chemistry Research Laboratory, M. M. A. M. Campus, Tribhuvan University, Biratnagar, Nepal
}

Email address:

prmmishra@rediffmail.com (P. Mishra)

\section{To cite this article:}

Surya Dev Prasad Yadav, Kalpana Mishra, Narendra Kumar Chaudhary, Parashuram Mishra. Assessing Physico-Chemical Parameters of Potable Water in Dhankuta Municipality of Nepal. Science Journal of Analytical Chemistry. Vol. 3, No. 2, 2015, pp. 17-21.

doi: 10.11648/j.sjac.20150302.11

\begin{abstract}
This paper intends to describe the physico-chemical parameters and bacteriological analysis of potable water used for drinking and domestic purposes in Dhankuta municipality of Nepal. The results obtained were compared with WHO and EPA standards for drinking and recreational water. The physico-chemical parameters used to quantify the quality of drinking water were $\mathrm{pH}$, alkalinity, TDS, DO, BOD, salinity, turbidity, heavy metals and anion measurements. The results of such analysis have been explained in discussion chapter of this paper and revealed tolerable to higher values as recommended by WHO standards. Total coliform and fecal coliform counts analyzed in the water samples were concluded the fecal and organic contaminations in the drinking water resources.
\end{abstract}

Keywords: Drinking, Physico-chemical Parameters, Vibrio Cholera, Gastro-Intestinal, Pathogens

\section{Introduction}

Nepal is a small land locked country located in between China and India. Ice capped Himalayas, glaciers and more than 100 small and big lakes make Nepal a richest source of water. Water is the most common, widely distributed and useful liquid on the earth [1]. Almost 2/3rd of earth's surface is covered by water existing in all the three major states. The human brain is $85 \%$ water, muscles and bones contain 77 and $33 \%$ water respectively. Good quality drinking water is of Fundamental importance to human physiology and has direct impact on health [2]. Water is considered as a superb solvent and a critical component that make the processes of life possible. Due to availability of minerals in water, it is essential for survival of life on earth. It is used in many ways from drinking to industrial and agricultural purposes [3]. Due to different physical and anthropogenic activities, there is degradation in the water quality, and it has direct impact on the climate and public health. Contamination by various pathogenic microorganisms and toxic chemical compounds in water are the main source of infectious diseases [4]. The quality of drinking water is a powerful environmental determinant of health. According to $\mathrm{WHO}, 80 \%$ diseases in the world are caused by inadequate sanitation, pollution and contaminated drinking-water. Assurance of drinking-water safety is a foundation for the prevention and control of waterborne diseases. Majority of today's groundwater contamination problems arise from human activities and can be introduced to the ground water from variety of sources like leaching of poisonous toxins and septic tank waste disposal [5]. Heavy metals $(\mathrm{Pb}, \mathrm{Cd}, \mathrm{Hg}$ and $\mathrm{As})$ contamination in drinking-water seriously threats human health at different levels of diseases. Arsenic is one of the poisonous materials which enter into the human body through drinking water causing many diseases [6]. In some areas of Nepal shallow and deep water reservoirs are highly contaminated with arsenic [7-8].

In Nepal, there is scarcity of drinking water, particularly in rural areas. The available water is of very poor quality. At the present situation, $85 \%$ urban and $11 \%$ rural populations have access to get piped water supply [9-11]. In many countries around the world including Nepal, drinking water supplies have become contaminated, which has impacted on the health and economic status of the populations.

Dhankuta is regional headquarter of eastern development zone of Nepal, where residents have access for potable water. As a result, water quality is of great concern. In Dhankuta municipality, the situation is worse and about $50 \%$ of the 
total population has access for proper water supply schemes. Natural water is generally used for drinking and other domestic purposes in this area. In the absence of fresh water supply, people residing in this area use bore wells water for their domestic and drinking purposes. However, an extensive analysis has not been conducted to determine quality of drinking water, so, this investigation aimed to evaluate its chemical. Physico-chemical parameters like $\mathrm{pH}$, alkalinity, TDS, BOD, turbidity, salinity, inorganic major anions and trace heavy metals were analysed to assess the quality of drinking water collected from different sample stations in Dhankuta municipality. Correlations between the metal concentrations were also investigated.

\section{Materials and Methods}

\subsection{Sample Preparation and Analysis}

All the chemicals and standards used for the preparation of reagents and solutions were of the highest purity analytical reagent grade available. Triple distilled water water was used throughout the analysis. Alkalinity of water samples were determined volumetrically by strong acid titration method. Total hardness was determined by complexometric titration method using standard EDTA with ammonia buffer and erichrome black ' $\mathrm{T}$ ' indicator [13]. Trace heavy metals like lead and arsenic contents were determined by standards prescribed by APHA using Varian Fast Sequential Atomic Absorption Spectrometer (model AA 240FS) [14]. The water samples for anion analysis were filtered using a hand operated vacuum pump equipped with a $0.45 \mu \mathrm{m}$ cellulose acetate filter membrane. Chloride was determined by using Volhard argentometric method. Sulphate $\left(\mathrm{SO}_{4}{ }^{2-}\right)$ and phosphate $\left(\mathrm{PO}_{4}{ }^{3-}\right)$ were determined by UV spectrophotometric method. $\mathrm{pH}$ was measured by using $\mathrm{Nel}$ $\mathrm{pH} 900$ digital $\mathrm{pH}$ meter with combined glass electrode. Conductivity was determined using a Jenway PCM1 portable conductivity meter. Prior to analysis, all instruments were calibrated according to manufacturer's recommendations. A Perkin-Elmer Analyst 100 model atomic absorption spectrometer equipped with deuterium background correction and HGA-800 graphite furnace was used for the heavy metal determinations.

\subsection{Sample Collection}

The drinking water for physic-chemical analysis were sampled from the site of consumers in prewashed (with detergent, doubly de-ionised distilled water, diluted $\mathrm{HNO}_{3}$ and doubly de-ionised distilled water respectively) polyethylene bottles from the different sampling stations, inside and outside of Dhankuta city. The water samples have been collected from both open and bore wells of various depths and stored in cool place for laboratory analysis. $\mathrm{pH}$ and conductivity were measured while collecting the samples. Two liters (one liter for the determinations of main ions and one liter for metal determination) of each water sample was taken in duplicate at two different sampling periods approximately 1 month apart. The determinations of the major ions of the water samples were performed within one week after sample collection. Drinking water was sampled from the site of consumers and analyses were carried out.

\section{Results and Discussion}

\subsection{Temperature}

In the present study, temperature in Sept. 20, 2014 ranged from 9.6 to $22.6^{\circ} \mathrm{C}$ and temperature in October-2014 ranged from 7.1 to $21.3^{\circ} \mathrm{C}$.

\subsection{Dissolved Oxygen (D.O.)}

In the present study, D.O. in Sept.20, 2014 ranged from 3.4 to $7.8 \mathrm{ppm}$. The minimum tolerance range is $4.0 \mathrm{ppm}$ for drinking water.

\subsection{Biological Oxygen Demand $\left(\mathrm{BOD}_{5}\right)$}

Biochemical Oxygen Demand (BOD) is a measure of the amount of oxygen consumed by microorganisms in the oxidation of organic matters in one liter water sample. When organic matter such as dead plants, leaves, grass clippings, manure, sewage, or even food waste is present in a water supply, the bacteria will begin the process of breaking down this waste. When this happens, much of the available dissolved oxygen is consumed by aerobic bacteria, robbing other aquatic organisms of the oxygen they need to live [15]. In the present investigation, $\mathrm{BOD}_{5}$ level ranged from 2.13.95 , which is below of tolerance limit 5 , recommended by WHO.

\section{4. $p H$}

Dissolved gases and industrial wastes affect the $\mathrm{pH}$ value of water and this finally changes the test of drinking water. In the present study, $\mathrm{pH}$ in Sept.20, 2014 ranged from 6.7 to 8.90. The tolerance $\mathrm{pH}$ limit is 6.5 to 8.5 . Some sample stations had higher $\mathrm{pH}$ than prescribed range. In Oct. 20, $2014 \mathrm{pH}$ ranged from 7.67 to 9.02 .

\subsection{Turbidity}

The turbidity in water refers to the loss of transparency caused by the presence of clay, organic matters, microscopic organisms and other particulate matters [16]. In the present study, turbidity in Sept. 20, 2014 ranged from 2.04 to 2.35 NTU and in Oct. 20, 2014 turbidity ranged from 0.16 to 2.60. The tolerance range for Turbidity is 5 NTU according to WHO guidelines. So the sample station has shown lower NTU values than the prescribed range.

\subsection{Electrical Conductance}

The electrical conductivity of water is due to dissolved mineral ions. All the water samples taken under investigation have measured electrical conductivities below WHO limit, which is $1500 \mu \mathrm{S} / \mathrm{cm}$. In the present investigation, electrical 
conductivity of the water samples was observed to be in the range of $234.7-235 \mu \mathrm{S} / \mathrm{cm}$.

\subsection{Total Dissolve Solid [T. D. S.]}

Various types of water soluble minerals and organic matters denote total dissolved solid. Concentration of dissolved solids in water is an important parameter that determines the quality of drinking-water [17]. The analytical data for all the water samples in our investigation ranged from $90.2 \mathrm{mg} / \mathrm{L}$ to $118 \mathrm{mg} / \mathrm{L}$, which is lower than WHO and National drinking water quality standard (NDWQS) value (1000 mg/L).

\subsection{Salinity}

In the present study, salinity in Sept. 20, 2014 ranged from 280 to $3160 \mathrm{ppm}$ and in Sept. 20, 2014 salinity ranged from 230 to $2350 \mathrm{ppm}$.

\subsection{Alkalinity}

Alkalinity is a measure of the acid buffering capacity of water. The alkalinity of water is due to the presence of hydroxide, bicarbonate and carbonate ions. The WHO limit for alkalinity of water is $200 \mathrm{mg} / \mathrm{L}$ and the permissible limit is $600 \mathrm{mg} / \mathrm{L}$, beyond this limit, the taste of water becomes unpleasant [18]. In the present investigation, the alkalinity of water samples ranged from $100-650 \mathrm{mg} / \mathrm{L}$.

\subsection{Phosphate}

In the present analysis, Phosphate in Sept. 20, 2014 ranged from 13 to $41 \mathrm{mg} / \mathrm{l}$ and in Oct. 20, 2014 Phosphate ranged from 10 to $39 \mathrm{mg} / \mathrm{l}$. The evaluated value of phosphate in the present study is higher than the prescribed value 14 . The higher value of phosphate is mainly due to the use of fertilizers and pesticides by the people residing in this area.

\subsection{Nitrate}

In the present analysis, nitrate in sampled water was ranged 56 to $420 \mathrm{mg} / \mathrm{L}$ for surface water which is due to excessive use of fertilizers in agriculture that sweep to reserved water used for drinking and domestic purposes. However the well water samples have very low nitrate content ie $0.84 \mathrm{mg} / \mathrm{L}$ which is far below the tolerance range 20-45 mg/L suggested by WHO [19].

\subsection{Sulphate}

In the present investigation, sulphate concentration of water samples ranged from 30.28 to $62.07 \mathrm{mg} / \mathrm{L}$ in Sept. 20, 2014 and 19.25 to $59.55 \mathrm{mg} / \mathrm{L}$ in Oct. 20, 2014. The tolerance limit range of sulphate is $200-400 \mathrm{mg} / \mathrm{L}$.

\subsection{Total Hardness}

Presence of divalent metal cations, especially calcium and magnesium in the form of bicarbonates and sulphates represent total hardness. It determines the quality of water for drinking and domestic purposes. In the presence study, total hardness in Sept. 20, 2014 ranged from 115 to 960 ppm and in Oct. 20, 2014 total hardness ranged from 85 to $820 \mathrm{ppm}$. The tolerance range for Total hardness is $300-600 \mathrm{ppm}$. More than tolerance limit in some sample stations indicated hard water which is unfit for drinking and domestic purposes. High levels of calcium and magnesium contents may be due to hill side locations of sample stations.

\subsection{Chloride}

Chloride is one of the major inorganic anion in water. In potable water, the salty taste is produced by the chloride concentrations. There is no known evidence that chlorides constitute any human health hazard. For this reason, chlorides are generally limited to $250 \mathrm{mg} / \mathrm{l}$ in supplies intended for public use as prescribed by WHO. In the present study, Chloride in Sept.20, 2014 ranged from 122.2 to 1465.7 $\mathrm{mg} / \mathrm{L}$ and in Oct. 20, 2014, it ranged from 68.9 to 1257.5 $\mathrm{mg} / \mathrm{L}$. The tolerance range for chloride is $200-1000 \mathrm{mg} / \mathrm{L}$.

\subsection{Fluoride}

In the present investigation, fluoride in different water samples ranged from 0.8 to $1.2 \mathrm{mg} / \mathrm{L}$. While the tolerance range for fluoride is 1.0 to $1.5 \mathrm{mg} / \mathrm{L}$. Low fluoride concentration prevents dental caries. However it has been observed that when fluoride intake through water, food and air increases to a specific level (1.0-1.2 $\mathrm{mg} / \mathrm{L})$ the beneficial effect is lost and in fact harmful effect begin to show with increasing concentration (above $1.5 \mathrm{mg} / \mathrm{L}$ ).

\subsection{Ammonia $\left(\mathrm{NH}_{3}\right)$}

In the present study, ammonia was found $1.04 \mathrm{mg} / \mathrm{L}$ which is under tolerance limit and was expected to come from organic matters in the water stream.

\subsection{Lead $(P b)$}

High lead contents in drinking water causes skin damage, circulatory system problems and increased risk of cancer. In the present investigation, the concentration of lead was below $0.005 \mathrm{mg} / \mathrm{L}$, which is under the tolerance limit.

\subsection{Arsenic (As)}

In the present investigation, arsenic was analyzed to be lesser than $0.005 \mathrm{mg} / \mathrm{L}$ which is below the tolerance limit suggested by WHO.

\section{Bactoriological Analysis}

The bacteria pathogens isolated from water samples in this work included Escherichia coli, Enterobacter aerogenes, Pseudomonas spp, Staphylococcus aureus, Salmonella typhosa, Shigella spp, Vibrio cholerae, Proteus spp, Klebsiella spp [20]. In the present investigation, the total coliform was found 8 counts $/ 100 \mathrm{ml}$ and fescal coliform was 6 counts $/ 100 \mathrm{ml}$. Accordingly, the total coliform count for all the samples were exceedingly high. This high coliform count 
obtained in the samples may be an indication that the water sources are fecally contaminated.

\section{Conclusion and Recommendation}

The different samples of potable water used for drinking and domestic purposes in Dhankuta municipality, collected from various places were found to have bacterial and mineral contaminations. Although some of the metals and anionic concentrations were under the tolerance limit but they may cause great human health problems. Hardness of water was beyond the tolerance limit. High anion concentration levels in drinking water samples also suggest that treatment is required for drinking purpose. However the $\mathrm{pH}$ level is variable at different sample sites. In conclusion, proper well location and construction, control of human activities to prevent sewage from entering water body are the keys for the bacterial contamination in drinking water.

It is evident that water borne diseases are due to improper disposal of refuse, contamination of water by sewage and surface runoff, therefore programmes must be organized to educate the general populace on the proper disposal of refuse, treatment of sewage and the need to purify water to make it fit for drinking because the associable organisms are of public health significance being implicated in one form of infection or the other. In areas lacking in tap water as in rural dwelling, educative programmes must be organized by researchers and government agencies to enlighten the villagers on the proper use of surface water.

\section{Acknowledgement}

The authors are grateful to SEAM-N-MMA environmental laboratory, Biratnagar, Nepal for providing the Perkin-Elmer 3110 atomic absorption spectrometers and Varian UV/Vis spectrophotometer used in the present study.

\section{References}

[1] Jasper M. Dalhuisen, Peter Nijkamp,(2006), Regulatory impacts on sustainable drinking water supply: a comparative study on Dutch water companies, Int. J. of Environmental Technology and Management Vol. 6, No.6 pp. 564 - 582.

[2] Timothy N. Mathieu, Alexander S. Rao,(2011), Identifying drinking water and water treatment systems vulnerabilities using the CARVER matrix method Int. J. of Critical Infrastructures Vol. 7, No.1 pp. 37 - 49

[3] G. Venkatesan, G. Swaminathan, R. Nagarajan,(2013),Study on groundwater quality in and around solid waste landfill site at Tiruchirappalli, Tamil Nadu, India,Int. J. of Environmental Engineering 2013 - Vol. 5, No.2 pp. 179 - 196

[4] E. Meneses-Ruiz, L.M. Turtos-Carbonell, I. OviedoRivero,(2004), Drinking water in Cuba and seawater desalination, Int. J. of Nuclear Desalination, Vol. 1, No.2 pp. 219 - 229.

[5] B. Ravichandran, S.K. Bhattacharya, A.K. Mukherjee, P.K.
Gangopadhyay, A. Roychowdhury, H.N. Saiyed (2012), Fluoride levels in drinking water and other surface water of an industrial area belt of Orissa State in India Int. J. of Environment and Pollution, Vol. 49, No.1/2 pp. 55 - 61.

[6] Heleno Luiz Dos Santos Junior, Gilson Lima Da Silva, Valdinete Lins Da Silva(2014), Qualitative analysis of the presence of emerging contaminants in water supplies for human use: a case study of the Guilherme de Azevedo reservoir in Caruaru (PE, Brazil) - Int. J. of Advanced Operations Management, Vol. 6, No.2 pp. 101 - 109

[7] Rabindra Nath Das, Jinseog Kim,(2012) GLM and joint GLM techniques in hydrogeology: an illustration, Int. J. of Hydrology Science and Technology Vol. 2, No.2 pp. 185 - 201.

[8] Francis Macary, Juscelino Almeida-Dias, Daniel Uny, Anne Probst(2013), Assessment of the effects of best environmental practices on reducing pesticide contamination in surface water, using multi-criteria modelling combined with a GIS Int. J. of Multicriteria Decision Making Vol. 3, No.2/3 pp. 178 - 211.

[9] Corine J. Houtman,(2010), A Sensitive and Specific Method for the Determination of N-Nitrosodimethylamine in Drinking Water and Fruit Drinks, Journal of Integrative Environmental SciencesVolume 7, Issue 4, pages 271-295.

[10] Jim Lemon, Richard Stevenson, Peter Gates \& Jan Copeland,(2011), Palatability, Familiarity, and Underage, Immoderate Drinking, Journal of Child \& Adolescent Substance AbuseVolume 20, Issue 5, pages 437-449.

[11] Benoit Barbeau, Annie Carrière \& Maryse F. Bouchard,(2011), Spatial and temporal variations of manganese concentrations in drinking water, Journal of Environmental Science and Health, Part A Volume 46, Issue 6, pages 608-616.

[12] H.M. Rafique, Iftikhar Abbas, Muhammad A. Sohl, Ramoona Shehzadi, Shahid Mahmood Ramay, Muhammad Imran, Yousef Al-Zaghayer, Asif Mahmood \& Maryia N. Sohl,(2014), Appraisal of drinking water quality of tehsil Jampur, Pakistan, Desalination and Water TreatmentVolume 52, Issue 25-27, pages $4641-4648$.

[13] Mir Misbahuddin \& Atm Fariduddin,(2013), Water Hyacinth Removes Arsenic from Arsenic-Contaminated Drinking Water, Archives of Environmental Health: An International JournalVolume 57, Issue 6, pages 516-518.

[14] Carol Ann Fronk,(2010), Destruction of Volatile Organic Contaminants in Drinking Water by Ozone Treatment, : Ozone: Science \& EngineeringVolume 9, Issue 3,pages 265-287.

[15] Xiang Zheng, Miao Yu, Heng Liang, Lu Qi, Hong Zheng, Harald Exler, Wernfried Schier \& Franz-Bernd Frechen,(2012), Membrane technology for municipal drinking water plants in China: progress and prospect, Desalination and Water Treatment, Volume 49, Issue 1-3, pages 281-295.

[16] Ángela Casado, Primitivo Ramos, Jaime Rodríguez, Norberto Moreno \& Pedro Gil,(2015), Feasibility of sulfide control in sewers by reuse of iron rich drinking water treatment sludge, Water Research, Volume 71, Pages 150-159.

[17] Joline El-Chakhtoura, Emmanuelle Prest, Pascal Saikaly, Mark van Loosdrecht, Frederik Hammes, Hans Vrouwenvelder,(2015), Dynamics of bacterial communities before and after distribution in a full-scale drinking water network, Water Research, In Press, Accepted Manuscript, Available online 17 February 2015. 
[18] Andrea M. Dietrich, Katherine Phetxumphou, Daniel L. Gallagher,(2014), Systematic tracking, visualizing, and interpreting of consumer feedback for drinking water quality, Water Research, Volume 66, 1 December 2014, Pages 63-74.

[19] Jonathan P. Ritson, Michael Bell, Nigel J.D. Graham, Michael R. Templeton, Richard E. Brazier, Anne Verhoef, Chris Freeman, Joanna M. Clark,(2014), Simulated climate change impact on summer dissolved organic carbon release from peat and surface vegetation: Implications for drinking water treatment, Water Research, Volume 67, 15 December 2014, Pages 66-76.

[20] Óluva K. Vang, Charlotte B. Corfitzen, Christian Smith, HansJørgen Albrechtsen,(2014), Evaluation of ATP measurements to detect microbial ingress by wastewater and surface water in drinking water, Water Research, Volume 64, Pages 309-320. 